\title{
Critical perceptions on problem-based learning
}

Citation for published version (APA):

Hemker, H. C. (2001). Critical perceptions on problem-based learning. European Review, 9(3), 269-274. https://doi.org/10.1017/S1062798701000254

Document status and date:

Published: 01/01/2001

DOI:

10.1017/S1062798701000254

Document Version:

Publisher's PDF, also known as Version of record

\section{Please check the document version of this publication:}

- A submitted manuscript is the version of the article upon submission and before peer-review. There can be important differences between the submitted version and the official published version of record.

People interested in the research are advised to contact the author for the final version of the publication, or visit the DOI to the publisher's website.

- The final author version and the galley proof are versions of the publication after peer review.

- The final published version features the final layout of the paper including the volume, issue and page numbers.

Link to publication

\footnotetext{
General rights rights.

- You may freely distribute the URL identifying the publication in the public portal. please follow below link for the End User Agreement:

www.umlib.nl/taverne-license

Take down policy

If you believe that this document breaches copyright please contact us at:

repository@maastrichtuniversity.nl

providing details and we will investigate your claim.
}

Copyright and moral rights for the publications made accessible in the public portal are retained by the authors and/or other copyright owners and it is a condition of accessing publications that users recognise and abide by the legal requirements associated with these

- Users may download and print one copy of any publication from the public portal for the purpose of private study or research.

- You may not further distribute the material or use it for any profit-making activity or commercial gain

If the publication is distributed under the terms of Article $25 \mathrm{fa}$ of the Dutch Copyright Act, indicated by the "Taverne" license above, 


\title{
Critical perceptions on problem-based learning
}

\author{
H. COENRAAD HEMKER \\ Tongersestraat 41, 6211 LM Maastricht, The Netherlands. E-mail: \\ HC.Hemker@Thrombin.com
}

\begin{abstract}
Problem-based learning (PBL), besides a number of advantages, also has drawbacks. It makes it very difficult for students to identify with a good teacher, and aims, rather, at identification with a peer group. Therefore, it seems more suited for adolescents than for young adults capable of secondary identification. Furthermore, this form of staff-student contact, i.e. the teaching group, does not motivate staff to share knowledge with the students. The knowledge acquired through PBL tends to remain unorganized. It is therefore more suited for disciplines in which a compilation of factual knowledge is important (e.g. medicine) than where a systematic approach is needed (e.g. statistics).
\end{abstract}

I was first confronted with problem-based learning (PBL) in 1974, when the ten people who started the medical faculty at Maastricht University adopted it as their general teaching policy. Wynand Wijnen was the driving force behind this decision and the others soon shared his enthusiasm. Suddenly, surrounded by people who loved PBL, I was neither enthusiastic nor opposed but I reserved my judgement. In fact, I did not find it worth my while to devote very much attention to the form of teaching and preferred to focus on content. Nevertheless, I was quite willing to join the experiment.

Fairly soon, the first drawback became apparent. PBL is, or was at that time, a revolutionary teaching system. Like all successful revolutions, it replaced one rigid system by another. Many reasonable objections to PBL were brushed aside because they were not in accordance with prevalent dogma. Now, I believe a western intellectual should draw his gun, loaded with independent thinking, as soon as he smells dogma in a university. So, although I started with an attitude of benevolent interest, I very soon became aware that rigorous application of PBL could lead to valuable assets of academic education being thrown overboard. Now, after 23 years of teaching experience, and approaching the end of my active participation in it, I still feel there are objections to PBL that need to be taken seriously, and I will try to define them.

My experience is in a faculty of medicine. In order not to confound the issue of PBL with the equally hot item of 'the scientific content' of medical studies, I will first dwell on the latter.

This article is an adapted version of 'Critical perceptions on problem-based learning' that appeared in Advances in Health Sciences Education, 3, 71-76, 1998, and is reproduced with permission of the publishers. 


\section{Science, medicine and teaching}

In the new faculty, I was to teach medical biochemistry because I was an $\mathrm{MD}$ and $\mathrm{PhD}$ who did research in haemostasis and thrombosis, a subject closely connected to the practice of medicine. You might expect that, as a biochemist, I judged PBL on its capacity to teach the science aspect in medicine. This, however, was not the case. Having gone through both medical and scientific training, I have concluded that medicine is rather a craft than a science. It is a craft that uses the results of science and requires a perception of what science is about, comparable to a carpenter being required to know the essentials of geometry. Admittedly, it is a highly sophisticated craft, but still it is a craft. This means that science is a servant to medicine, although, of course, it is an important - and probably the most important - servant.

A good doctor does not necessarily have to be a good scientist. He should help his patients, unhindered by fundamental doubts about prevailing knowledge or preoccupation with unsolved problems. He should use the results of science and he should know how to use them with plain common sense. On top of that, a good doctor should have a large number of other qualities a scientist does not need, such as the capacity to cope with lack of sleep and a keen interest in his fellow human beings. I therefore feel that a medical education should not breed scientists, but doctors with a basic understanding of the role of science in medicine. And even this limited confrontation with science is still a confrontation. At least it has been in our type of PBL. Those who teach medicine according to the principles of PBL seem to be suspicious of the natural sciences. Clinical cases are apparently considered to be sufficient to make students acquainted with knowledge of the wider scientific context of medicine. I can tell you that they are not. Although the scientific background of medicine is something that may indeed be learned through a problem-based method, it requires a closer cooperation between scientists and doctors than is currently often the case. The scientific content of the curriculum at my faculty has improved over the years, yet there is still a tendency to avoid exercises in hard science, even problem-based ones.

Let me give you an example. In 1975, I wanted our first-year students to learn something about how biological molecules interact. The PBL specialists, however, objected very strongly, because 'easier problems should come before more difficult ones'. That is why I was told that they had to replace my molecular problems by psychological ones. This is a fallacy. What is confused is the threshold to the problem and the inherent difficulty to solve the problem. Once you are introduced to them, molecules will turn out to be infinitely less complex than people.

I can only guess what causes this resistance to scientific problems. It is certainly not because scientific problems cannot be presented in a problem-oriented way. One explanation might be that the teaching specialists, who, as a rule, are not fundamental scientists, are afraid of losing control. Anyhow, as a consequence of this attitude, we have delivered several generations of students with a defective knowledge of basic science and scientific thinking. As I explained before, I think that a deficiency in knowledge of scientific facts may not be too serious for a doctor. However, if students are insufficiently exposed to scientific thinking during their years at the university, the opportunity is lost forever and irreparable harm may be done.

A lack of scientific content in PBL may also cause scientists in the faculty to become less engaged. They may turn away from teaching and devote most of their time to research. This may go so far as to split the faculty into two parties: a teaching nomenclature and a 
research Mafia. There is a fundamental, teaching-based reason to try to avoid this. A university is the only place where research and teaching can have equal and mutually compatible roles. If this is lost, one of the main advantages of a university is gone.

\section{Three objections against PBL}

To come to the point: What are my main objections against PBL? I have classified them in three categories.

- PBL makes it very difficult for students to identify with a good teacher.

- PBL does not motivate staff to share knowledge with the students.

- The knowledge acquired through PBL tends to remain unorganized.

\section{Identification and learning}

In animals and young children, imitation of those with whom they identify is the basis of all learning processes. Identification on the basis of an object relation, that is primary identification, is the natural process behind the larger part of all our learning. In other words, both animals and human beings desire to be like the ones they love. This is a normal and healthy process. In puberty, the primary identification with the parents wanes, and often is opposed. Identification with peers, or with whatever idol may present itself, may take the place of parent identification. When children are in that age, identification often smacks of idealization. Ideally, the young adult that emerges is capable of secondary identification. This means that he or she is free to determine where to find his or her objects of identification, and can do so without a sense of guilt. Very often, the objects of identification are the great characters in the profession that catch his or her fancy and, if he or she is lucky, these greats are his or her teachers.

Higher education has a long history of great and admired teachers whose names still resound in our modem world. From Socrates to Niels Bohr, the words of the masters have been respected and repeated. The phenomenon is universal. We see it not only in science but also in the arts and crafts. Whether it is painting or cooking, 'la mémoire du geste', the direct example of somebody who excels in the art is the superior way of teaching. Top-quality teaching of musicians, for example, is entirely based on having a good teacher and allowing a pupil to identify with him or her. In short, at all levels the natural way of learning is by means of identification. In adult learners, this is secondary identification, engaged in freedom and with an open eye for the human dimensions of the master.

It is very important for a student in medicine to be given the opportunity to choose his or her identification-relations between the best doctors and scientists available. The wisdom behind the traditionally heavy procedures to nominate professors in our universities is precisely that only the best should be offered the right to teach. I have to admit, though, that this sounds better in theory than it tends to turn out in practice.

You may object that a patient is not a violin, that it is primarily knowledge that counts in making a doctor. Still, I maintain that handling a patient is very much a skill, like playing the violin is. It is, however, a far more difficult skill. Not doing it well has more far-reaching 
consequences than playing a false note or hearing an occasional scratch. On the other hand, unlike musical errors, medical mistakes often go unnoticed.

There are attitudes and skills that cannot be learned in a skills lab or through attitude training. They require personal contact between teacher and student. Paradoxically, this personal contact is virtually independent of the size of the class. What matters is the 'size' of the teacher. Teaching in small tutorial groups randomizes contacts between students and staff. Furthermore, the tutor is not selected because of his or her professional aptitude and teaching capabilities. On the contrary. By guiding the student rather than teaching him, he deprives the student of the opportunity to see a master at work. Hence, he is deprived of one of the main mechanisms of personal development.

There is one type of person that identifies much easier with peers than with a teacher - the adolescent. Somebody who is in that period of life does not feel free to select an object of identification that resembles a parent, because s/he is still loosening the parental tethers. Problem-based learning in groups seems to be made to measure for them. I believe, however, that the teaching of medical students should be aimed at young adults rather than at adolescents.

Those who defend PBL are not in favour of identification with a teacher. They defend their point of view by stressing the negative effects of identification pushed too far, by confusing secondary identification with idealization. Yet blindly adhering to a group, sect, faith or person and ignoring the negative sides completely is not what adult, secondary identification is about. Identifying is okay as long as you realize that you should be free to select whatever you want or do not want to adopt. This is hard intellectual and emotional labour, of which not everybody is capable. The attraction of scientology and other sects is a logical consequence of this incapability of critical identification, of falling into the trap of idealization. For a mature personality, nobody and nothing is worthy of being blindly adopted as an ideal - not even PBL.

So, in summary, PBL makes identification with a teacher almost impossible. It deprives the mature student of an important mechanism of learning. PBL requires identification with a system and a peer group and is therefore probably more suited for adolescents. PBL has efficiently precluded the danger of unwanted idealization of the individual teacher, but not that of idealization of itself.

\section{Staff are no longer motivated to share knowledge with the students}

Wynand Wijnen, the driving force behind the introduction of PBL at my school, told me himself: he hated his teachers and he hates teaching. This may be of more than anecdotal importance. Ever since I was confronted with PBL. I have suspected the specialists of the silent aim of taking the fun out of teaching. Teaching is fun. I admit that this fun is based on narcissism, but so what? Of course, the great professors whose courses I remember, such as Borst for internal medicine, Presser for history, Bernet Kempers for musicology and Jean Bernard for haematology, were as narcissistic as any great actor, musician or politician; but again, if this makes them perform well, there is no harm done. Is there?

To be chosen as an object of identification is to be chosen as worthy of an object relation, to be worthy, if not of love, at least of respect. It goes without saying that this is a narcissistic gratification. The longing for this gratification is what causes good teachers, musicians, actors etc, to go to great lengths to give the best of themselves. The atmosphere in which PBL 
developed was hostile to such gratification of the individual teacher. Teaching in PBL is primarily organizing and guiding group processes. The only loyalty it involves is loyalty is to an impersonal system and to an ever-changing group of peers. Teachers in the PBL system are denied the fun of sharing with their students their own processes of understanding.

If PBL is motivating for the students, and I will not deny that it is, then it is equally de-motivating for good teachers. The question of what is more important remains. As we have seen above, motivation is particularly important during puberty. More mature people should not need to be motivated. The very least that a medical student can do if he or she is not motivated is shut up. We should not forget, and they should not forget, that they are a highly privileged lot. For every student that is granted admittance to medical school, and in the Netherlands they are allocated by means of a 'lottery', there is another young person that is dying to be admitted but is not entitled to.

\section{The knowledge acquired by the students tends to remain badly organized}

Having a subject explained by an experienced scientist or clinician is particularly useful in acquiring the attitude and skills necessary to organize knowledge, learning to distinguish between essential and accessory knowledge. One of the worst courses I was ever required to follow was a course in pharmacology where the professor did nothing but read a book, his own. Those who defend PBL often cite this type of instance to illustrate the inadequacy of frontal teaching. Indeed, in Dutch academic history, there is the famous example of the professor who took an early retirement five years before he was due to stop, because the notes from which he had taught anatomy for the past 15 years had been burnt in a fire. Of course there are bad teachers, and those reading from a book are among the worst. Why? Probably because books have a tendency to aim at completeness. Writers of textbooks are like Russian novelists. They usually resist the temptation to say something in seven pages if they can also say it in 30 . That is why it takes a clever student to extract the essentials from a book. The ordinary and the mediocre student, whom we should focus our efforts on, often needs guidance in distinguishing between the essential and the less important. Such guidance is difficult to obtain from books. When I tried to learn the principles of thermodynamics from a single book, I found it utterly impossible. Only studying several different books at the same time made it possible to grasp the essentials. Our students usually restrict their studies to one book, usually not selected because of its outstanding educational properties, but because it is in Dutch. This may explain why the knowledge that our students acquire is very often like that from a bookcase that has toppled over. They often know a large number of isolated facts and phrases but have problems distinguishing between what is important and what is not. Their knowledge lacks the organization that comes with long experience or that comes from being introduced to a subject by someone that has this long experience. This effect may be reinforced by our method of examination.

\section{Conclusions}

Now what is my conclusion? Should we do away with PBL? I do not think so-for the good reason that the method of teaching is less important than the contents of what we teach. After 
all, a doctor is formed during the practical work with patients in the first years after he has left school rather than during his classes. Irrespective of the system that is adopted, the best students will always succeed. The bad will always fail, I hope. This means that the teaching method only serves to determine what type of mediocre student will be most happy. Students seem to be happy with PBL, so why not adopt PBL? If you decide to adopt it, try to pay special attention to the structure of the knowledge that you offer and do not forget that it is useful for a doctor to have some insight in the ways of science. Most importantly, make teaching less teacher-independent lest students are precluded from all forms of identification. And try to organize teaching in such a way that it remains fun for both your scientific staff and your students. In short, PBL is like democracy: it is not ideal and it can always be ameliorated. However, one should not like to do without. As for democracy, two hurrahs will do, three would be exaggerating.

\section{About the author}

H. Coenraad Hemker is a biochemist. He was one of the founders of the University of Maastricht and was its Rector Magnificus 1982-85. His scientific interest has been in haemostasis, and this continues in Maastricht and also at the Mount Sinai School of Medicine in New York. 